\title{
A Study of Leukocyte and Platelet Activity in Patients with Suicide Attempt Related to Acute Stres Reaction
}

\author{
Emel Koçer ${ }^{1}$, Aytekin Alçelik², Gülșen Kocaman, Abdulkadir Koçer ${ }^{3}$
}

ÖZET:

Akut stres reaksiyonu ile ilişkili olarak intihar girişiminde bulunan hastalarda lökosit ve trombosit aktiviteleri üzerine bir çalıșma

Amaç: Akut stres reaksiyonu (ASR) sıklıkla depresyonla birlikte görülür ve stresle ilișkili hormonlar trombosit birikimiyle ilişkili arteriyel trombozda önemli rol oynarlar. Bilgimize göre ASR ile ilișkili bir intihar girișimi sonrasında lökosit ve trombosit sayımını deg̃erlendiren çalıșma yoktur.

Yöntem: Bu çalıșmada kan lökosit, trombosit ve ortalama trombosit hacim (MPV) düzeyleri incelendi. ilave olarak, bu parametreleri etkileyen etmenler deg̃erlendirildi. Acile bașvuran ve intihar girişimi sonrasında aynı psikiyatrist tarafından deg̃erlendirilen hastalara ait veriler toplandı. Aynı bölgede yașayan sag̃lıklı örneklem grubu kontrol grubu olarak kabul edildi. Vaka-kontrol çalıșması olarak dizayn edilen bu çalıșmada 30 intihar girișimi vakası ve yaș ve cinsiyet olarak uygun 33 kontrol vakası analize tabi tutuldu.

Bulgular: İntiharla ilișkili ASR tanısı olan 30 kișinin kontrollerle karșılaștırılmasında kan sonuçları artmış lökosit düzeyi saptanırken trombosit sayısı ve MPV düzeyleri benzer bulundu. Takipte, trombosit düzeyi hasta grubunda daha düșük düzeylerde bulundu ( $p=0.001$ ) ve bu düșüklük intihar amaçlı antidepresan kullanımı ile ilișkiliydi $(p=0.003)$.

Sonuç: ASR sonrasında trombosit sayısı veya MPV düzeyi artmadı, fakat lökosit sayısında artıs gözlemlendi. ilaveten, çalıșmamız antidepresan ilaçlarla ilişkili anti-trombosit etkinin varlıg̃ını da desteklemekteydi.

Anahtar sözcükler: akut stres reaksiyonu, intihar, trombosit, lökosit, ilaçlar, anti-depresan, analjezik

Journal of Mood Disorders 2013;3(2):52-7

\section{ABSTRACT:}

A study of leukocyte and platelet activity in patients with suicide attempt related to acute stres reaction

Aim: Acute stress reaction (ASR) is often seen with depression, and stress-related hormones may play an important role in acute arterial thrombosis by increasing platelet aggregation. To the best of our knowledge, no study has examined leukocyte and platelet counts following a suicide attempt with ASR. Method: The present study examined blood leukocyte, platelet and mean platelet volume (MPV) levels. In addition, we examined the factors affecting these parameters. Data for patients who were admitted to the emergency room and evaluated by same psychiatrist after a suicide attempt were obtained from the health registries. Controls were selected from all residents living in the same area. Using a casecontrol design, we examined 30 suicide cases and 33 controls matched for gender and age.

Results: The 30 subjects diagnosed with ASR related suicide showed increased white blood cell counts but similar platelet counts and mean platelet volume compared with controls. At follow-up, the platelet count was lower in patients than in controls $(p=0.001)$, which was related to suicide attempts by using anti-depressants $(p=0.003)$.

Conclusion: ASR did not increase platelet count or MPV, but we found an increase in leukocyte counts following ASR. Additionally, our study supported the antiplatelet effect of antidepressant medications.

Key words: acute stress reaction, suicide, platelet, leucocyte drugs, antidepressant, analgesic

Journal of Mood Disorders 2013;3(2):52-7
'Bezmialem Vakif University Medical Faculty, Psychiatry Department, Istanbul-Turkey 2Bolu izzet Baysal University Medical Faculty, Internal Medicine Department, Bolu-Türkiye ${ }^{3}$ Medeniyet University Medical Faculty, Neurology Department, Istanbul-Turkey

Yazlșma Adresi / Address reprint requests to: Emel Kocer, Bezmialem Vakif University, Medical Faculty, Psychiatry Department, Istanbul-Turkey

Telefon / Phone : +90-505-426-2828

Elektronik posta adresi / E-mail address: dremelkocer@yahoo.com

Kabul tarihi / Date of acceptance: 4 Nisan 2013 / April 4, 2013

Bag̃ntı beyanı:

E.K., A.A., G.K., A.K.: Yazarlar bu makale ile ilgili olarak herhangi bir çıkar çatıșması bildirmemiștir.

Decloration of interest:

E.K., A.A., G.K., A.K.: The authors reported no conflict of interest related to this article.

\section{INTRODUCTION}

Depression and acute stress reaction (ASR) are the most common diagnoses for suicide attempts $(1,2)$. ASR is a diagnosis given immediately following the experience of an exceptional mental or physical stress (1). ASR increases suicide risk, and subjects with ASR and coexisting depression or substance abuse have elevated suicide rates than expected based on the independent effects of these conditions $(3,4)$. Increases in circulating leukocytes in response to acute psychological stress or short-term intensive exercise is a well-documented phenomenon (5). The effects of stress on circulating white blood cells (WBCs) have been experimentally studied in a number of animal species and or general increases in total WBCs, has been occasionally used as a measure of stress $(6,7)$.

Altered platelet function is observed in patients with depression (3). Platelet aggregation and mean platelet 
volume (MPV) are increased in patients with depression (8-10). ASR is often seen with depression, and stress-related hormones may fulfil an important role in acute arterial thrombosis by increasing platelet aggregation $(2,4,11)$.

To the best of our knowledge, no study has examined the association between ASR and hematological changes. Therefore, the current study aimed to examine the association between ASR and the number of leukocytes and platelets in a hospital-based population. We hypothesized that ASR would be associated with a higher number of leukocytes compared with healthy adults without a diagnosis of ASR. The second objective was to examine MPV, which is a practical indicator of platelet activity and platelet count, in patients with ASR in comparison with healthy volunteers $(12,13)$. Additionally, we examined medications taken following suicide attempts as modifiers of these associations.

\section{MATERIALS AND METHODS}

\section{Patients}

The study was conducted in an emergency clinic from June 2009 to June 2010. Thirty patients (22 women and 8 men) meeting the ICD-10 criteria for an acute stress reaction (ASR) (1), but not for a current episode of major depressive disorder and 33 physically and mentally healthy, aged 18 years or older comparison subjects (23 women and 10 men) who were similar in age and sex to the patients with acute stres reaction were recruited. Controls were screened for DSM-IV (14) Axis I disorders. Patients with ASR were ineligible to participate in the study if they met any of the following exclusion criteria: 1-Existence of any other mental disorders i.e. depression, psychosis, conversion; 2-Treatment with any drugs such as antithrombotics within 2 weeks before entry; 3-Pregnancy, or history of severe drug allergy or hypersensitivity; 4-History of hematological problem or malignancy; 5-Treatment with anti-depressants within 4 weeks before entry; and 6-Suicide attempt 3 hour after admission to hospital. Clinically significant abnormalities on the baseline physical examination, electrocardiogram, or laboratory test results were also criteria for exclusion from study participation. All the patients were newly diagnosed as ASR in emergency room, and were followed up for 3 to 5 days. The agents used for suicide attempts were recorded.
They have taken only supportive therapy. Written, informed consent was obtained for each patients. The study was conducted in accordance with the Declaration of Helsinki. The study was approved by the Local Ethics Committee of Duzce University, Medical School.

\section{ASR Diagnosis}

The diagnosis of ASR was assessed through a semistructured clinical interview. According to the ICD-10 Classification, the symptoms of acute stress reaction must be present within 1 hour of the stressful or traumatic event and include one autonomic arousal symptom (e.g. sweating, heart palpitations or shaking). In addition, symptoms from three of the following categories must be present: chest and abdomen symptoms (e.g. difficulty in breathing, feeling of choking or chest pain), brain and mind symptoms (e.g. feeling dizzy, feeling that objects are unreal or fear of dying), general symptoms (e.g. numbness or chills), muscle and mental tension symptoms and other non-specific symptoms (e.g. being easily startled, difficulty concentrating or irritability).

\section{Biochemical Measurements}

Blood samples were drawn within 3 hours after ASR i.e. suicide. Soon after, acute treatment protocols were applied in emergency rooms. After 3 to 5 days, blood samples were redrawn from the patients. Blood samples of patients in $2^{\text {nd }}$ measurements and controls were drawn after a fasting period of 12 hours. We measured leukocyte count, MPV and platelet count in a blood sample collected in citrate $(1: 4 \mathrm{vol} / \mathrm{vol})$ to avoid the platelet swelling induced by EDTA. The expected values for leukocyte count, platelet count, and MPV in our laboratory ranged from 3.8 to $10.2 \times 10^{3} / \mathrm{uL}$, from 140 to $450 \times 10^{3} / \mathrm{uL}$, from 7 to $11 \mathrm{fL}$ respectively.

\section{Statistical Analysis}

Statistical analysis was done by SPSS statistical software (SPSS 11 for Windows). Data were tested for normal distribution using the Kolmogorov-Smirnov test. All data showing uniform distribution and baseline parameters of patients and normal controls were compared by t test, others by Mann-Whitney test. In 
comparison of three or more variables, One-Way ANOVA or Kruskal-Wallis tests were used. Paired t test was used to determine whether there was a significant difference between basal and posttreatment variables. Pearson correlation was used to see correlations. Data are expressed as mean \pm SD. Statistical significance was defined as $\mathrm{p}<0.05$.

\section{RESULTS}

The mean age of patients and controls were $24.97 \pm 8.13$ and $27.21 \pm 6.34$ years, respectively $(\mathrm{p}=0.22)$. Our patients attempted suicide for seeking relief from feeling ashamed, guilty, or like a burden to others $(n=12)$ and feelings of rejection, loss, or loneliness $(\mathrm{n}=18)$. They also reported that their suicidal behaviors were triggered by emotional trauma $(n=15)$, dependence on alcohol or other drugs $(n=5)$, unemployment or financial problems $(n=5)$, death of a loved one $(n=3)$, and serious physical illness $(n=2)$. Ten patients used anti-depressants (5 sertraline, 3 citalopram, 2 paroxetine), 9 patients used different analgesics (6 paracetamol, 2 diclophenac sodium, 1 naproxene sodium), and 11 patients used different agents (3 insecticides, 3 patient antipsychotics, 2 people proton pump inhibitors, 2 people antiepileptics) for suicide attempt. Those drugs reported above were belong to people in his/her family. In admission, all patients had decreased consciousness, i.e. 4 people had stupor, 10 people had deep sleep, and others had confusion. The clinical and laboratory parameters of the study population are reported in Table 1 . The effect of anti-depressants and analgesics were evaluated in statistical analysis as seen in Table 2. At first measurements, mean leukocyte count was significantly higher in group with ASR ( $p=0.003$ ) than in controls. This significancy was

Table 1: The comparison of WBC and platelet counts, and MPVs in each measurement

\begin{tabular}{|c|c|c|c|c|c|c|c|}
\hline & Variable & Grup & $\mathbf{N}$ & Mean & $\begin{array}{l}\text { Std. } \\
\text { Deviation }\end{array}$ & $\begin{array}{l}\text { Std. } \\
\text { Error Mean }\end{array}$ & p value \\
\hline FIRST & WBC count & Patients & 30 & 9.71 & 3.80 & .718 & 0.003 \\
\hline \multirow[t]{7}{*}{ MEASURE } & & Controls & 33 & 7.48 & 1.58 & .27 & \\
\hline & Platelet count & & & & & & \\
\hline & & Patients & 30 & 268.10 & 76.56 & 14.21 & $0.092^{*}$ \\
\hline & & Controls & 33 & 289.12 & 57.84 & 10.06 & \\
\hline & MPV & & & & & & \\
\hline & & Patients & 30 & 8.41 & 1.36 & .25 & $0.783^{*}$ \\
\hline & & Controls & 33 & 8.33 & 1.63 & .28 & \\
\hline SECOND & WBC count & Patients & 30 & 7.76 & 2.61 & .48 & 0.609 \\
\hline \multirow[t]{7}{*}{ MEASURE } & & Controls & 33 & 7.48 & 1.59 & .27 & \\
\hline & Platelet count & & & & & & \\
\hline & & Patients & 30 & 239.07 & 49.74 & 9.23 & 0.001 \\
\hline & & Controls & 33 & 289.12 & 57.85 & 10.06 & \\
\hline & MPV & & & & & & \\
\hline & & Patients & 30 & 8.30 & 1.11 & .20 & $0.783^{*}$ \\
\hline & & Controls & 33 & 8.33 & 1.63 & .28 & \\
\hline
\end{tabular}

t-test, Mann-Whitney*

Table 2: The comparison of WBC (White Blood Cell) and platelet counts, and MPVs (Mean Platelet Volumes) in order to see the effects of anti-depressant and analgesics used for suicidal aim

\begin{tabular}{|c|c|c|c|c|}
\hline Variables & Controls $(n=33)$ & $\begin{array}{l}\text { Patients took } \\
\text { analgesics }(n=9)\end{array}$ & $\begin{array}{l}\text { Patients took } \\
\text { anti-depressants }(n=10)\end{array}$ & p value \\
\hline $1^{\text {st }}$ WBC count & $7.48 \pm 1.58$ & $9.55 \pm 3.22$ & $10.51 \pm 5.19$ & 0.01 \\
\hline $2^{\text {nd }}$ WBC count & & $8.56 \pm 2.95$ & $7.29 \pm 2.04$ & 0.29 \\
\hline $1^{\text {st }}$ Platelet number & $289.12 \pm 57.84$ & $306.22 \pm 103.89$ & $241.4 \pm 58.01$ & $0.10^{*}$ \\
\hline $2^{\text {nd }}$ Platelet number & & $256.33 \pm 48.52$ & $221.50 \pm 39.55$ & 0.03 \\
\hline $1^{\text {st }} M P V$ & $8.33 \pm 1.63$ & $8.06 \pm 0.71$ & $9.36 \pm 1.78$ & 0.28 \\
\hline $2^{\text {nd }} M P V$ & & $8.35 \pm 0.87$ & $8.73 \pm 1.54$ & $0.68 *$ \\
\hline
\end{tabular}

ANOVA, Kruskal Wallis* 
related especially to antidepressants (Table 2, $\mathrm{p}=0.01$ ). However, statistically significant difference of leukocyte count between the groups disappeared at the $2^{\text {nd }}$ measurements. No significant difference was observed between the groups regarding MPV and platelet count at the $1^{\text {st }}$ results. The change of laboratory parameters in patients with ASR during the study period are given in Table 2 . At the $2^{\text {nd }}$ measurements, the platelet count was lower in patients as seen in Table $1(\mathrm{p}=0.001)$. The platelet count was found to be significantly decreased compared with the value of controls after the $2^{\text {nd }}$ measurements in patients who took anti-depressants for suicide ( $\mathrm{p}=0.003$ ). There was also a significant decline in platelet count of patients who took antidepressants for suicide in comparison of 2 measurements ( $\mathrm{p}=0.028$ ).

\section{DISCUSSION}

Blood cells are sensitive indicators of physiological and pathophysiological responses in humans. In our study, we found that leukocyte (WBC) counts increased in ASR patients compared with controls. Although mean MPV values were higher and platelet counts were lower in patients, they were statistically indifferent in comparison to controls. Patients who took antidepressants following a suicide attempt showed decreased platelet counts at follow-up $(\mathrm{p}<0.05)$. This effect was independent of the dosage and the type of selective serotonin reuptake inhibitor (SSRI) administered. Similarly, MPV tended to decrease when compared with the initial measurement ( $>0.05$ ). In our patients we assessed WBC (leukocyte) count as an indicator of ASR. We have found that leukocytosis was apparent in $1^{\text {st }}$ measurements. Leukocytosis is a well-known response to acute psychological stress $(5,15,16)$. Both psychological stress and exercise have significant effects on cellular expression of adhesion molecules leading to increases in the number of circulating leukocytes and lymphocyte subsets. Maes and colleagues demonstrated that academic examination stress was accompanied by signs of immune activation, such as an increase in leukocytes $(5,15,16)$.

Patients with major depressive disorder exhibit alterations in multiple platelet parameters, including a reduction in serotonin transporter $[3 \mathrm{H}]$-imipramine binding sites in platelets (17) and increases in 5HT2receptor binding sites on the platelet surface (18). In other words, patients with depression exhibit increased platelet activation. Because ASR may occur together with depression, we looked for changes in platelet function in patients with ASR. Pozzi and colleagues revealed that stress-related hormones might increase platelet aggregation in patients with ASR (11). In contrast, De Jong and colleagues reported that low platelet count was related to increases in serum cortisol, and they concluded that low $\mathrm{pH} /$ bicarbonate and low platelet count as well as increased disease severity and organ failure were predictors of a subnormal increase in serum cortisol upon ACTH stimulation in a large series of critically ill patients (19). Furthermore, steroids may inhibit platelet aggregation induced by arachidonic acid, which may result in a dose-dependent decrease in the magnitude of aggregation (20). In the present study, we found normal platelet function (platelet count and MPV). Our findings were similar to some reports in the literature $(21,22)$. Gupta and colleagues showed that steroids did not affect platelet count (21). Additionally, Schuerholz and colleagues reported that hydrocortisone mediated the immunomodulating effects of therapy in patients suffering from septic shock, without involvement of specific platelet receptors in vitro (22).

Several reports have suggested an antiplatelet effect of antidepressant medications, although the exact mechanisms are still uncertain $(4,23-26)$. SSRIs have antithrombotic and fibrinolytic activity (27). Nearly all serotonin in the body is stored within platelets, and peripheral serotonin plays important roles in platelet aggregation and the regulation of vascular tonus. Furthermore, SSRIs increase central nervous system serotonin, while reducing serotonin within the platelets, and this release reduces platelet aggregation (28). Inhibition of platelet aggregation by SSRIs in response to ADP followed by inhibition of the reuptake of serotonin into platelets results in reduced platelet aggregability (2830). In our study, we assessed platelet activity by measuring platelet count and MPV. Our findings were similar to previous studies suggesting that antidepressant treatment reduces platelet (hyper) activity $(10,24,31,32)$. The results of the present study also indicate that highdose SSRIs cause a decrease in the size and number of platelets in patients with ASR. Our findings provide evidence that high concentrations of SSRIs inhibit platelet activity within a short time period (within 3-5 days). 
In summary, we believe we are the first to use MPV and platelet count as indicators of platelet activity in patients with ASR. We found that patients with ASR did not exhibit increased platelet activity, but our findings supported the antiplatelet affects of antidepressants, and this effect continued during subsequent days.

\section{References:}

1. World Health Organization. The ICD-10 classification of mental and behavioral disorders: diagnostic criteria for research. Geneva: World Health Organization, Division of Mental Health, 1993.

2. Okulate GT. Suicide attempts in a Nigerian military setting. East Afr Med J. 2001;78:493-6.

3. Kim CK, McGorray SP, Bartholomew BA, Marsh M, Dicken T, Wassertheil-Smoller S, Curb JD, Oberman A, Hsia J, Gardin J, Wong ND, Barton B, McMahon RP, Sheps DS. Depressive symptoms and heart rate variability in postmenopausal women. Arch Intern Med. 2005;165:1239-44.

4. Gradus JL, Qin P, Lincoln AK, Miller M, Lawler E, Sørensen HT, Lash TL. Acute stress reaction and completed suicide. Int J Epidemiol. 2010;39:1478-84.

5. Maes M, Van Bockstaele DR, Gastel A, Song C, Schotte C, Neels H, DeMeester I, Scharpe S, Janca A. The effects of psychological stress on leukocyte subset distribution in humans: evidence of immune activation. Neuropsychobiology. 1999;39:1-9.

6. Ots I, Murumagi A ,Horak P. Haematological health state indices of reproducing Great Tits: methodology and sources of natural variation. Functional Ecology. 1998;12:700-7.

7. Davis AK, Maney DL, Maerz JC. The use of leukocyte profiles to measure stress in vertebrates: a review for ecologists. Funct. Ecol. 2008;22:760-72.

8. Williams L. Depression and Stroke: Cause or Consequence? Semin Neurol. 2005;25:396-409.

9. Serebruany VL, Glassman AH, Malinin AI, Nemeroff CB, Musselman DL, van Zyl LT, Finkel MS, Krishnan KR, Gaffney M, Harrison W, Califf RM, O'Connor CM. Sertraline AntiDepressant Heart Attack Randomized Trial Study Group. Platelet/endothelial biomarkers in depressed patients treated with the selective serotonin reuptake inhibitor sertraline after acute coronary events: the Sertraline AntiDepressant Heart Attack Randomized Trial (SADHART) Platelet Substudy. Circulation. 2003;108:939-44.

10. Ataoglu A, Canan F. Mean platelet volume in patients with major depression: effect of escitalopram treatment. J Clin Psychopharmacol. 2009;29:368-71.

11. Pozzi AO, Bernardo E, Coronado MT, Punchard MA, González P, FantidisP.Acutearterial thrombosisin the absence ofinflammation: the stress-related anti-inflammatory hormone ACTH participates in platelet-mediated thrombosis. Atherosclerosis. 2009;204:79-84.

12. Yetkin E. Mean platelet volume not so far from being a routine diagnostic and prognostic measurement. Thromb Haemost. 2008;100:3-4.

13. Muscari A, De Pascalis S, Cenni A, Ludovico C, Castaldini N, Antonelli S, Bianchi G, Magalotti D, Zoli M. Determinants of mean platelet volume (MPV) in an elderly population: relevance of body fat, blood glucose and ischaemic electrocardiographic changes. Thromb Haemost. 2008;99:1079-84.
14. Diagnostic and statistical manual for mental disorders, $4^{\text {th }}$ ed: DSM-V.Washington, DC: American Psychiatric Association, 1994.

15. Benschop RJ, Rodriguez-Feuerhahn M, Schedlowski M. Catecholamine-induced leukocytosis: early observations, current findings and future directions. Brain Behav Immun. 1996;10:77-91.

16. Goebel MU, Mills P. Acute Psychological Stress and Exercise and Changes in Peripheral Leukocyte Adhesion Molecule Expression and Density. Psychosomatic Medicine. 2000;62:664-70.

17. Nemeroff CB, Knight DL, Krishnan RR, Slotkin TA, Bissette G, Melville ML, Blazer DG. Marked reduction in the number of platelet-tritiated imipramine binding sites in geriatric depression. Arch Gen Psychiatry. 1988:45;919-23.

18. Hrdina PD, Bakish D, Ravindran A, Chudzik J, Cavazzoni P, Lapierre YD. Platelet serotonergic indices in major depression: up-regulation of 5-HT2A receptors unchanged by antidepressant treatment. Psychiatry Res. 1997;66:73-85.

19. de Jong MFC, Beishuizen A, Spijkstra JJ, Girbes ARJ, van Schijndel S, Twisk JWR, Groeneveld ABJ. Predicting a low cortisol response to adrenocorticotrophic hormone in the critically ill: a retrospective cohort study. Crit Care. 2007;11:61.

20. Glass F, Lippton H, Kadowitz PJ. Effects of methylprednisolone and hydrocortisone on aggregation of rabbit platelets induced by arachidonic acid and other aggregating substances. Thromb Haemost. 1981;46:676-9.

21. Gupta S, Earley B, Ting ST, Crowe MA. Effect of repeated regrouping and relocation on the physiological, immunological, and hematological variables and performance of steers. J Anim Sci. 2005;83:1948-58.

22. Schuerholz T, Keil O, Wagner T, Klinzing S, Sumpelmann R, Oberle V, Marx G. Hydrocortisone does not affect major platelet receptors in inflammation in vitro. Steroids. 2007;72:609-13.

23. Morel-Kopp MC, McLean L, Chen Q, Tofler GH, Tennant C, Maddison V, Ward CM. The association of depression with platelet activation: evidence for a treatment effect. J Thromb Haemost. 2009;7:573-81.

24. Flöck A, Zobel A, Bauriedel G, Tuleta I, Hammerstingl C, Höfels S, Schuhmacher A, Maier W, Nickenig G, Skowasch D. Antiplatelet effects of antidepressant treatment: A randomized comparison between escitalopram and nortriptyline. Thromb Res. 2010;126:837.

25. Maurer-Spurej E. Serotonin reuptake inhibitors and cardiovascular diseases: a platelet connection. Cell Mol Life Sci. 2005;62:159-70.

26. Maurer-Spurej E, Pittendreigh C, Solomons K. The influence of selective serotonin reuptake inhibitors on human platelet serotonin. Thromb Haemost. 2004;91:119-28.

27. Szasz R, Dale GL. COAT platelets. Curr Opin Hematol 2003;10:3515. 
28. Askın R, Herken H. Selektif serotonin geri alım inhibitörleri ve beklenmeyen yan Etkileri. Klinik Psikofarmakoloji Bülteni. 1998;8:249-50.

29. Hourani S, Cusack N. Pharmacologic receptors on blood platelets. Pharmacol Rev. 1991;43:243-98.

30. Declerck F. The role of serotonin in thrombogenesis. Clinical Physiology and Biochemistry. 1991;8:40-9.
31. Atar D, Malinin A, Takserman A, Pokov A, van Zyl L, Tanguay JF, Lesperance F, Serebruany VL. Escitalopram, but not its major metabolites, exhibits antiplatelet activity in humans. J Clin Psychopharmacol. 2006;26:172-7.

32. Atar D, Malinin A, Pokov A, van Zyl L, Frasure-Smith N, Lesperance F, Serebruany VL. Antiplatelet properties of escitalopram in patients with the metabolic syndrome: adoseranging in vitro study. Neurospsychopharmacology. 2007;32:2369-74. 